University of Pennsylvania Carey Law School

Penn Law: Legal Scholarship Repository

Faculty Scholarship at Penn Law

$5-25-2014$

\title{
Antitrust and the Close Look: Transaction Cost Economics in Competition Policy
}

Herbert J. Hovenkamp

University of Pennsylvania Carey Law School

Follow this and additional works at: https://scholarship.law.upenn.edu/faculty_scholarship

Part of the Antitrust and Trade Regulation Commons, Economic Theory Commons, Industrial Organization Commons, and the Law and Economics Commons

\section{Repository Citation}

Hovenkamp, Herbert J., "Antitrust and the Close Look: Transaction Cost Economics in Competition Policy" (2014). Faculty Scholarship at Penn Law. 1836.

https://scholarship.law.upenn.edu/faculty_scholarship/1836

This Article is brought to you for free and open access by Penn Law: Legal Scholarship Repository. It has been accepted for inclusion in Faculty Scholarship at Penn Law by an authorized administrator of Penn Law: Legal Scholarship Repository. For more information, please contact PennlawIR@law.upenn.edu. 


\title{
Antitrust and the Close Look:
}

\section{Transaction Cost Economics in Competition Policy}

\author{
Herbert Hovenkamp*
}

Since the 1970s Transaction Cost Economics (TCE) has become an increasingly powerful tool in antitrust analysis. At that time the reigning but embattled school of antitrust in the courts was structuralism, or the structure-conduct-performance (S-C-P) paradigm, which saw market structure as the principal determinant of anticompetitive behavior and poor economic performance. ${ }^{1}$ Within that model, which was closely associated with Harvard's economics department and law school, structure entailed conduct of a certain kind, and this conduct entailed poor performance. As a result conduct dropped out as a variable of interest and one could reason directly from structure to performance. S-C-P's promoters tended to believe that monopoly power and its exercise were widespread. ${ }^{2}$ Building on a neoclassical model in which sellers placed their goods on an anonymous market and purchasers bought them in single-shot transactions, they were suspicious of deviations from common law contract models for distribution. The result was elevated fears of both ownership vertical integration and vertical contractual practices such as tying, exclusive dealing, resale price maintenance or related restraints. Antitrust policy became hostile toward all of them. At its core lay the "leverage" theory, which feared that a monopolist could easily "exploit] his dominant position in one market to expand his empire into the next."

At the other extreme was the Chicago school position, whose theory of vertical integration began with the collapse of the "leverage" theory in the $1950 \mathrm{~s},{ }^{4}$ and developed into a more general argument that most vertical ownership and contract integration should be lawful per se..$^{5}$ The Chicago school also tended to see the economic landscape in terms of competition and monopoly, but they saw far fewer situations where monopoly could be created or maintained for long periods.

The critique of the leverage theory showed that in a basic tying situation a firm with market power and the ability to charge prices above cost could not increase its

*Ben V. \& Dorothy Willie Professor of Law, University of Iowa.

${ }^{1}$ See Herbert Hovenkamp, The Neal Report and the Crisis in Antitrust, 5 COMPETITION POL'Y INT'L 217 (2009). On the S-C-P paradigm's development and dominance prior to its collapse, see Herbert Hovenkamp, United States Competition Policy in Crisis, 1890-1955, 94 MINN.L.REV. 311 (2009).

${ }^{2}$ See, e.g., CARL KAYSEN \& DONALD F. TURNER, ANTITRUST POLICY: AN ECONOMIC AND LEGAL ANALYSIS (1959); JOE S. BAIN, INDUSTRIAL ORGANIZATION (1959); JOE S. BAIN, B ARRIERS TO NEW COMPETITION: THEIR CHARACTER AND CONSEQUENCES IN MANUFACTURING INDUSTRIES (1956).

${ }^{3}$ Eastman Kodak Co. v. Image Tech. Servs., Inc., 504 U.S. 451, 479 n.29 (1992).

${ }^{4}$ See, e.g., Ward Bowman, Jr., Tying Arrangements and the Leverage Problem, 67 YALE L.J. 19 (1957); and see Richard A. Posner, The Chicago School of Antitrust Analysis, 127 U. PA. L. REV. 925 (1979).

${ }^{5}$ These views were consolidated and popularized by ROBERT H. BORK, THE ANTITRUST PARADOX: A POLICY AT WAR WITH ITSELF (1978); see also Richard A. Posner, The Next Step in the Antitrust Treatment of Restricted Distribution: Per Se Legality, 48 U. CHI. L. REV. 6 (1981). 
overcharge by tying or other forms of vertical integration. To the contrary, in the case of successive or complementary firms with market power, combining two products or process stages into a single firm would actually increase output and reduce price by eliminating double marginalization. Tying was thought mainly to be a form of price discrimination, which permitted a monopolist to extract more profits but also typically increased output. As a result there was no reason based on economic welfare grounds for condemning ties.

Since the 1970s both the old Harvard and the traditional Chicago positions have moved from opposite directions toward the middle. To say that the rise of transaction cost economics is solely responsible for this re-alignment of antitrust policy is an exaggeration. However, TCE has helped antitrust develop a new "center," which has influenced both the case law and the academic literature. TCE's analytic tools serve to critique both the leverage theory and the belief that pricing and vertical practices are virtually never anticompetitive. The result has been to position antitrust analysis somewhat closer to Chicago's "benign" position than to the inherent hostility position reflected by structuralism and the traditional leverage theory.

In The Nature of the Firm (1937), Coase argued that the costs of using the market determine the boundaries of the firm. ${ }^{6}$ A firm intent on maximizing its value chooses internal production up to the point that the marginal cost of producing internally equals the marginal cost of external procurement, and vice versa. Firms in a bargaining relationship that have specialized commitments to a common technology or resource do precisely the same thing. They maximize value by bargaining with each other to the point that the marginal payoff of reaching a bargain equals the marginal payoff of moving on.

Following after Coase, TCE generally assumes that business firms organize their activities so as to maximize their value, which they can do both by economizing and also by obtaining higher prices. Sensible antitrust policy recognizes that both advantageous contracting and monopoly can be profitable to a firm, and it can be expected to pursue both when they are available. Nevertheless, the opportunities for economizing are many, while those for monopoly are relatively few.

Further, firms always evaluate alternatives from their present perspective, which necessarily includes the consequences of past decisions. The movement of resources from the current position is costly, and one of these costs is that of relying on the market. $^{7}$ One of the first choices firms must make is whether to use internal production or external procurement for a particular input or process. When products and distribution are specialized, many of a firm's contractual arrangements with others must

\footnotetext{
${ }^{6}$ See Ronald H. Coase, The Nature of the Firm, 4 ECONOMICA (n.s.) 386 (1937); Herbert Hovenkamp, Coasean Markets, EUR.J.L. \& ECON. _ (2010), available at http://papers.ssrn.com/sol3/papers.cfm?abstract id=1580059; Herbert Hovenkamp, Coase, Institutonalism, and the Origins of Law and Economics, 85 IND. L.J. (forthcoming 2010), available at http://papers.ssrn.com/sol3/papers.cfm?abstract_id=1538279.

${ }^{7}$ See Herbert Hovenkamp, Antitrust and the Costs of Movement, __ ANTITRUST L.J. _ (2011), available at http://papers.ssrn.com/sol3/papers.cfm?abstract id=1679849.
} 
necessarily be of long term and somewhat open ended, in the sense that they do not anticipate every conceivable circumstance. Product differentiation tends to produce specialization at all levels, and this has two effects. First, it tends to make firms larger vertically, because the cost of internal production is relatively lower and the cost of market procurement relatively higher. Secondly, insofar as a firm uses external procurement its contractual relationships become more durable and more complex because the parties must often make substantial commitments to the technologies and product designs of their trading partners. ${ }^{8}$ While all participants are rational, they do not have perfect information and they almost always know more about themselves than about others. A rational firm anticipates that, to the extent uncertainty exists, everyone in the market will try to use new situations to their own advantage, itself included.

Transaction cost economics builds on these insights, which determine not only what a firm's boundaries will be, but also who are likely to be its bargaining partners in outside markets and what those bargains will look like. For example, an exclusivity provision in a contract permits a firm to retain some of the control and disciplinary advantages of internal production, while sharing investment costs and risk.

Finally, one of the many costs of resource movement is the administrative cost of the cumbersome and imperfect machinery antitrust uses to analyze and deter anticompetitive practices. To the extent that the goal of competition policy is to increase wealth, administrative costs may counsel that certain practices be left unchallenged because the gains from enforcement will not exceed losses when enforcement costs themselves, including error costs, are included. ${ }^{9}$

This framework generally produces antitrust rules that are more benign than the old "hostility" tradition, but somewhat more aggressive than the Chicago school promoted. Transaction costs and other resource movement costs provide benign explanations for many practices that the hostility tradition condemned. But transaction costs can also create entry barriers or make other forms of market movement sticky and thus increase both the possibility and duration of monopoly. In a well functioning market a manufacturer and its dealers will bargain to the maximizing position, which is typically the position that benefits consumers as well. In the real world, however, transaction costs may enable dealer cartels or powerful individual dealers to impose restraints that are competitively suboptimal for both the manufacturer and consumers. ${ }^{10}$ In that case, antitrust has a role to play.

The fundamental unit of analysis for TCE is the transaction, rather than the much broader set of goods or servies that constitute a market in ordinary economic analysis. ${ }^{11}$ Equally important is the question of who transacts with whom. A distinctive feature of TCE is that it does not assume that each trader has a range of trading partners that is coextensive with the product and geographic market at issue. Rather, transactions

\footnotetext{
${ }^{8}$ OLIVER E. WiLliAMSON, THE MECHANISMS OF GOVERNANCE 66, 93-119 (1996).

${ }^{9}$ See HERBERT HOVENKAMP, THE ANTITRUST ENTERPRISE: PRINCIPLE AND EXECUTION 54-56 (2005).

${ }^{10}$ See 8 Phillip E. AREedA \& Herbert HovenKamp, ANTITRUST LAW $q 1604$ (3d ed. 2010).

${ }^{11}$ OLIVER E. WiLliAMSON, THE ECONOMIC INSTITUTIONS OF CAPITALISM 15-42 (1985).
} 
occur in a setting that limits the range of trading partners depending on knowledge, previous investment or technological commitment, and past history. This limited range in turn affects the types of contracts that the partners make with one another.

By virtue of previous commitments (asset specificity), pairs of firms are thrust into positions where the potential net payoff of reaching a further bargain is greater than the payoff of abandoning this position and starting over. ${ }^{12}$ What makes these situations interesting is that firms seek them out because there are gains to be had from joint specialization. Bargaining in such markets typically yields arrangements and practices that seem inconsistent with perfect competition-transfer prices that are above cost, price discrimination and nonlinear pricing, exclusivity provisions, tying and bundling, and contractual impositions on the prices, locations, and practices of trading partners. In classical political economy goods were generic and distribution was unspecialized. As a result, everyone traded with everyone else. Building on this premise, the leverage theory was inclined to be suspicious of situations where specific buyers and sellers in the distribution process were locked in to one another by long term contractual requirements. This suspicion accounts for many of the harsh rules that antitrust applied to vertical contractual practices as well as vertical ownership integration through the 1970s. ${ }^{13}$

Historically Chicago school writers understood that these practices are perfectly consistent with general competitive conditions, but their focus on the impossibility of leveraging inclined them not to see any opportunities for harm whatsoever. That is, they tended to believe that no contract a monopolist or dominant firm made, other than collusion with rivals, would enable it to reduce output profitably more than it was already doing.

The dedicated vertical relationships whose analysis has been a centerpiece of TCE often behave like bilateral monopolies in the sense that within them price is indeterminate and bargaining complex. For example, if a manufacturer with market power has costs of $\$ 4$, distribution costs of $\$ 3$, and the profit-maximizing price is $\$ 10$, there are $\$ 3$ in economic profits to be made. If the manufacturer can sell efficiently through a competitive dealer network it will retain the markup for itself, permitting the dealers only a competitive return. However, if dealers are specialized and their market is limited, the dealers themselves may have power to bargain with the manufacturer over how the overcharge is distributed among them. In an unstructured setting this lack of a determinate price can produce high transaction costs, double marginalization, or both. $^{14}$

In most vertical business contracting settings, however, the contractual form establishes a "hierarchy" that imposes stability, although not necessarily joint

\footnotetext{
${ }^{12}$ Benjamin Klein, Robert G. Crawford \& Armen A. Alchian, Vertical Integration, Appropriable Rents, and the Competitive Contracting Process, 21 J.L. \& ECON. 297 (1978).

${ }^{13}$ On this point, see Herbert Hovenkamp, The Law of Vertical Integration and the Business Firm, 95 IOWA L. REV. 863 (2010).

${ }^{14}$ On the economics of bilateral monopoly, see ROGER D. BLAIR AND JEFFREY L. HARRISON, MONOPSONY IN LAW AND ECONOMICS 123-145 (2d ed. 2010)..
} 
maximization. For example, in the typical franchise setting the franchisor establishes a contract form and strikes a deal with each franchisee individually. The franchisees may have little opportunity to collaborate with each other or cycle through counteroffers. In this respect the structure of the franchise arrangement resembles a business firm more than a market. Retail detailers often make investments that are specific to a particular manufacturer's product, and manufacturers for their part make investments in these dealers. This is how bilateral monopoly relationships get started, but both manufacturers and dealers embrace such opportunities. Indeed, the entire principle behind the development of modern contractual distribution systems is that the gains more than offset any transaction problems that arise from this form of co-investment. The same thing applies to supply agreements. For example, General Motors and Fisher Body Works were once two highly specialized firms whose production was "locked" together by previous design commitments. ${ }^{15}$

Simple bilateral monopoly is not an antitrust problem, even if it increases transaction costs, unless the firms committed to such relationship have market power in at least one external market. Costly bargaining and advantage taking might implicate contract or perhaps tort law. But no arrangement that they make has antitrust significance as long as they lack market power; external prices will not be affected. This was the error that the Supreme Court majority made in the 1992 Kodak case. The customers' purchase of durable Kodak photocopiers placed them into a bilateral monopoly relationship with Kodak to the extent that the customers needed aftermarket parts that only Kodak could supply. In his dissent Justice Scalia likened the situation to a bilateral monopoly -- one in which a swimming pool contractor discovers a five-ton boulder buried in the customer's yard after excavation is well under way. ${ }^{16}$ Transaction costs will be magnified if such problems are not specified in advance, at the time of initial contracting. However, residential back yards and swimming pool contractors are both competitive, and the resolution of this dispute will have no impact on the market price or output of homes, homes with swimming pools, contracting services, or any other antitrust market that might be relevant to the dispute.

When at least one firm in a distribution market has serious market power, however, the welfare of consumers depends more on well functioning distribution markets. At that point, if bargaining breaks down, antitrust may have a role to play. For example, suppose that $A$ is a monopoly manufacturer of a product and $B$ is its monopoly dealer, or $B$ represents a cartel of all of $A$ 's dealers in a particular retail market. In a well functioning market $A$ and $B$ should be able to negotiate to the profit-maximizing output. The division of the profits is indeterminate, but consumers would be indifferent to that outcome as well because the final price would be the same. The extent of monopoly will not be greater because the firm in question uses restrictive contracts to distribute its product, provided that the dominant firm and its dealers reach the joint maximizing agreement.

${ }^{15}$ See Ronald H. Coase, The Acquisition of Fisher Body by General Motors, 43 J.L. \& ECON. 15 (2000); see also Benjamin Klein, Vertical Integration as Organizational Ownership: The Fisher BodyGeneral Motors Relationship Revisited, 4 J.L. ECON. \& ORG. 199 (1988).

${ }^{16}$ Eastman Kodak Co. v. Image Tech. Servs., Inc., 504 U.S. 451, 497 (1992) (Scalia, J., dissenting). 
If the manufacturer and the dealer(s) both have market power in their respective output markets, however, the bilateral monopoly situation threatens double marginalization, which does injure consumers. To illustrate, a gasoline refiner with market power might face a double-marginalization problem if a gasoline retailer downstream, or a cartel of retailers, have market power in the retail market as well. The manufacturer would sell to the dealer(s) at a price that the manufacturer determines by equating its own marginal cost and marginal revenue; that is, it would take a monopoly markup. The dealer with market power of its own would then accept that price as given and add its own monopoly markup. The price is suboptimal for everyone concerned. Both the manufacturer and dealer would be better off if they could agree on a "joint maximizing" output and price level, which would be the same one as if there was only one monopoly in the distribution chain. Consumers would also be better off under a single monopoly.

Double marginalization problems occur in both vertically related markets and markets for complements. ${ }^{17}$ The transaction cost problem is typically more serious for complements than vertically related firms because producers of complementary products, such as computers and printers, often are not in a position to deal with each other.

Double marginalization is fundamentally a transaction cost problem. ${ }^{18}$ That is, with zero transactions costs vertically related firms with market power would agree on the joint maximizing output, but in fact they frequently do not. A precondition to double marginalization is that both firms have some market power and that one firm is not in a position to avoid the power of the other at low cost by dealing with someone else. In cases of oligopoly there might be more than one firm at each level, but each of the firms has some market power. Since pricing in excess of marginal cost is common in product-differentiated markets, ${ }^{19}$ double marginalization is common as well.

As a general proposition firms faced with double marginalization have three choices:

(1) accept the consequences of double marginalization, which might be the best alternative if internal production is costly and alternative (3) is unavailable; for example, a manufacturer selling to a market-dominating local dealer may have no choice but to accept that dealer's high markups as a cost of doing business; everyone involved including consumers are injured.

(2) integrate by ownership into the other production level, whether by merger or new entry; or

${ }^{17}$ See, e.g., Giuseppe Dari-Mattiacci \& Francesco Parisi, Substituting Complements, 2 J. COMPETITION L. \& ECON. 333 (2006).

${ }^{18}$ See Herbert Hovenkamp, Harvard, Chicago, and Transaction Cost Economics in Antitrust Analysis, 55 ANTITRUST BULL. 613, 634-637 (2010); for more technical treatment, see W. KIP VISCUSI, JOSEPH E. HARRINGTON, JR., \& JOHN M. VERNON, ECONOMICS OF REGULATION AND ANTITRUST 238-41 (4th ed. 2005).

${ }^{19}$ See, e.g., Robert E. Hall, The Relation between Price and Marginal Cost in U.S. Industry, 96 J. PoL. ECON. 921 (1988). 
(3) the "bargaining" solution, which is to enter into one of many types of contractual arrangements under which the two vertically related firms increase output and cut price toward the joint maximizing level.

Recognizing that both options (2) and (3) can result in lower prices and higher output, antitrust would respond with a more benign attitude toward vertical new entry, vertical acquisitions, and vertical contracting, although not necessarily with per se legality. This of course requires examination of the economics of various types of distribution contracts. Perversely, antitrust policy has been counterproductive to the extent that it has prohibited the parties from reaching a bargain that will maximize their joint profits.

An easy case is maximum resale price maintenance, which is readily explained by double marginalization concerns. The manufacturer limits the dealer's markup to an approximation of the competitive level. Assuming that the dealer cannot enlarge its markup in other ways, such as by reducing valuable services, the manufacturer can get back to its optimal monopoly price level. If the manufacturer is a monopolist, that price will reflect no more than the amount of power that it has. If the manufacturer is a competitor, then the output price should be competitive as well. For example, in the State Oil case, which adopted a rule of reason for maximum RPM, the individual dealer may have had power in its local retail market but there was no reason for thinking that State Oil, a relatively small player in the much larger supply market, had significant market power. ${ }^{20}$

The same thing is true of quantity and loyalty discounts, which can enable a manufacturer and dealer to share the gains that result from increasing output to the joint-maximizing level. The discount operates like an economy of scale, enabling the dealer to achieve lower costs by selling more of the manufacturer's product. ${ }^{21}$

A loyalty, or market share, discount differs from a quantity discount in that the discount is fixed to a percentage of the reseller's purchases rather than an absolute quantity or dollar amount. ${ }^{22}$ Loyalty discounts are often better than quantity discounts for both manufacturers and consumers when the downstream market is concentrated. Quantity discounts discriminate against smaller firms that are unable to purchase in the same volume as larger firms. As a result, quantity discounts can give larger firms a price umbrella or in extreme cases even drive smaller firms out of the market altogether. Once again, the concern is essentially of double marginalization: the manufacturer wants to keep the downstream market as competitive as possible, and keeping smaller

\footnotetext{
${ }^{20}$ State Oil Co. v. Khan, 522 U.S. 3 (1997); see §11.5c; and 8 ANTITRUST LAw, Ch.16C (3d ed. 2010).

${ }^{21}$ See 11 Herbert HovenKamP, AnTITRUst LaW I1807 (3d ed. 2011); Bruce H. Kobayashi, The Economics of Loyalty Discounts and Antitrust Law in the United States, 1 COMPETITION POL'Y INT'L 115 (2005).

${ }^{22}$ For other double marginalization issues that might be addressed by market share discounts akin to exclusive dealing, see Gianluca Faella, The Antitrust Assessment of Loyalty Discounts and Rebates, $4 \mathrm{~J}$. COMPETITION L. \& ECON. 375 (2008); Sreya Kolay, Greg Shaffer \& Janusz Ordover, All-Units Discounts in Retail Contracts, 13 J. ECON. \& MGMT. STRATEGY 429 (2004).
} 
firms in the market facilitates this goal. Otherwise the price reduction for purchasing more will be offset by increased market power given to the larger dealers as the smaller dealers are denied the discount.

Transaction cost analysis also explains many tying arrangements and bundled discounts, which occur when a seller offers a discount to one who purchases two or more different products together. ${ }^{23}$ Many famous old tying cases involved tied products that were commodities sold in highly competitive markets, such as dry ice in the Carbice case or salt in International Salt. ${ }^{24}$ In those cases price discrimination rather than controlling double marginalization very likely explained the tie. The typical tied products today, however, are manufactured products sold in product-differentiated markets. ${ }^{25}$ The one exception is fast food franchises, where the tied product is often food items or supplies that are almost certainly sold in highly competitive markets. ${ }^{26}$

Tying almost always involves complementary products-that is, products that are more valuable if they are used together. As noted previously, the doublemarginalization problem for complements, often called the "Cournot complements" problem, is similar to the one for vertical distribution. ${ }^{27}$ The complementary goods problem might involve something like a computer and a printer, an MP3 digital music player and downloaded music, or a computer operating system and software applications. In such cases the printer manufacturer will charge its profit-maximizing price for the printer, and the cartridge manufacturer will do the same for its cartridge. The two separate markups can be significantly higher than the combined markup that would be taken by a firm that sold both products together. Further, profits would be higher for the single firm than for the two firms separately, and consumers would be better off because output would be higher and prices lower. Complementary rights in intellectual property sold by separate firms can lead to the same result, such as the "royalty stacking" that occurs when different firms own patents that are essential to the production of some good or process. ${ }^{28}$ In such cases welfare would be increased if a single firm sold the complementary goods.

\footnotetext{
${ }^{23}$ See Erik Hovenkamp and Herbert Hovenkamp, Exclusionary Bundled Discounts and the Antitrust Modernization Commission, 53 ANTITRUST BULL. 517 (2008); Erik Hovenkamp \& Herbert Hovenkamp, Complex Bundled Discounts and Antitrust Policy, 57 BufFALO L.REV. 1227 (2009).

${ }^{24}$ Carbice Corp. v. Am. Patents Dev. Corp., 283 U.S. 27, 31-32 (1931); Int'1 Salt Co. v. United States, 332 U.S. 392 (1947).

${ }^{25}$ E.g., Static Control Components, Inc. v. Lexmark Int'1, Inc., 487 F. Supp. 2d 861 (E.D. Ky. 2007) (denying summary judgment on claim that printer/cartridge technological tie was unlawful).

${ }^{26}$ E.g., Queen City Pizza, Inc. v. Domino's Pizza, Inc., 124 F.3d 430, 433 (3d Cir.1997) (tied product was pizza dough; dismissing complaint based on "lock in" theory of power); Burda v. Wendy's Intern., Inc., 659 F.Supp.2d 928 (S.D.Ohio 2009) (nonmonopoly franchisor; tied product was hamburger buns; sustaining complaint based on lock in theory of market power); Martrano v. Quizno's Franchise Co., LLC, 2009 WL 1704469 (W.D.Pa. June 15, 2009, unpublished) (nondominant fast food franchisor; tied product was unspecified supplies and services; dismissing complaint for failing to allege appropriate relevant market).

${ }^{27}$ See, e.g., JEAN TIROLE, THE THEORY OF INDUSTRIAL ORGANIZATION 175-76 (1988).

${ }^{28}$ See Mark A. Lemley \& Carl Shapiro, Patent Holdup and Royalty Stacking, 86 TEX. L. REV. 1991 (1996). On devices for addressing the problem, see CHRISTINA BOHANNAN \& HERBERT HOVENKAMP,
} 
Assume that firm $A$ makes a computer while firm $B$ makes a compatible printer. Most but not all customers purchase one of each and they are both sold in oligopoly markets at prices above cost. Given that these prices maximize individual profits, neither firm wishes to cut the price of its own product. At this point firm $A$ would have an incentive to acquire firm $B$, or vice versa, or perhaps it would enter the printer market on its own. Firm A's profit-maximizing price for a computer/printer combination would be lower than the sum of the prices charged by the separate firms. Firm $A$ would also earn more, output would be higher, and consumers would benefit as well.

Firm A could accomplish this in two ways. It could simply tie computers and printers, refusing to sell the two separately. That would benefit those consumers who wanted one of each, but it would injure those who needed only one of the two products, perhaps as a replacement. Alternatively, it could charge the single product profitmaximizing price for each product separately but a lower price for the combination-that is, it would use a bundled discount to eliminate double marginalization for those buyers who regarded the goods as complements at the time of purchase. ${ }^{29}$

But why shouldn't we force the firm simply to offer the computer and the printer separately at the lower prices? For example, suppose that the individual profitmaximizing prices of the computer and printer are $\$ 1000$ and $\$ 400$, respectively, while the profit-maximizing price for the package when sold by a single firm is $\$ 1200$. Would it not be preferable on policy grounds to require the manufacturer to sell the two products separately at, say, $\$ 900$ and $\$ 300$ ? This would eliminate the double marginalization and it might satisfy those who find the tie unacceptable on some other ground.

First of all, if none of the rival printer companies cut their price to match then the result would be the same as tying in any event. That is, the buyer would take both from firm $A$. Second, however, if one or more of the other printer companies did cut the printer price to $\$ 300$, then firm $A$ would not capture all of the printer sales. A premise of the double-marginalization story is that the price cut on the printer is profitable because the manufacturer obtains the higher output that accrues to both the computer and the printer. If it cannot tie and be assured of getting all of the printer sales, then it will not cut its price.

The double-marginalization explanation of tying and related practices is robust and has broad application in markets characterized by single firm dominance or product differentiation. Tying and bundled discounts can operate as a kind of "reverse leverage" in cases where both the bundled products are sold in less than perfectly competitive markets.

The other side of the double-marginalization problem is that high transaction costs may interfere with manufacturers' efforts to control it by contract. A good example

CREATION WITHOUT RESTRAINT: COMPETITION POLICY IN INNOVATION INTENSIVE MARKETS, ch. 8 (2011).

${ }^{29}$ See Erik N. Hovenkamp \& Herbert Hovenkamp, Tying Arrangements and Antitrust Harm, 52 ARIZ. L. REV. (2010). 
is vertical price and nonprice restraints, an area where the TCE literature has made important contributions. The free rider explanation for these restrictions, which dates to the 1960s, is but one example. ${ }^{30}$ Manufacturers use resale price maintenance and nonprice restraints in order to achieve some of the efficiencies of intrafirm distribution while preserving the risk sharing and incentive features of contractual distribution mechanisms. For example, a firm distributing its own product would ordinarily provide the optimal level of distribution services. By using RPM it can emulate this level when using independent dealers and alternative enforcement mechanisms are too costly or ineffectual. By the same token the self-distributing manufacturer would sell its full product line through each store. In a contractual distribution network it may have to offer inducements to dealers to carry the full line, often by using RPM in order to guarantee margins on the more popular goods so as to prevent "cream skimming" by other retailers. ${ }^{31}$ Alternatively, a single firm engaged in self-distribution would place the optimal number of stores in a community, and a firm engaged in contractual distribution would try to replicate that allocation by using territorial restrictions or other limits on dealer location.

However, there may also be situations in which vertical agreements exacerbate double marginalization and high transaction costs prevent efficient solutions from emerging. For example, antitrust legitimately has an interest in the problem of dealer cartels or powerful individual dealers. ${ }^{32}$ Well-placed local dealers may be in a position to exercise market power in their individual retail markets. Depending on their power vis-à-vis the manufacturer, they may be able to extract RPM on competing dealers for their own benefit, but to the detriment of an efficient distribution system. The cost of moving resources being what it is, it may be less costly for the manufacturer to comply than to set up alternative equally satisfactory dealerships. The result will be higher local prices. $^{33}$ Once again, this is fundamentally a problem of transaction costs. If bargaining worked perfectly, a manufacturer and its dealers would agree on the joint maximizing output level and negotiate over the division of profits. But when a powerful established dealer can frustrate this by insisting on higher local markups a manufacturer may be powerless to resist, particular if vertical integration into retailing is not possible on account of the need for distribution by multiproduct retailers. Dr. Miles itself was such a case, involving RPM instigated by a cartel of retail druggists. ${ }^{34}$

Another area where transaction cost analysis has led to changes in antitrust analysis is price discrimination, which occurs when a firm obtains higher ratios of price to marginal cost from some buyers than from others. Systematic price discrimination does not occur under perfect competition because, by definition, some prices are not at marginal cost. So price discrimination presupposes at least some power to set a price

\footnotetext{
${ }^{30}$ See Lester G. Telser, Why Should Manufacturers Want Free Trade?, 3 J.L. \& ECON. 86 (1960).

${ }^{31}$ See 8 AREEDA \& HOVENKAMP, ANTITRUST LAW IIII 1614f, 1615d.

${ }^{32} I d .$, II 1604.

${ }^{33}$ See, e.g., Toledo Mack Sales \& Serv., Inc. v. Mack Trucks, Inc., 530 F.3d 204 (3d Cir. 2008)

${ }^{34}$ See HERBERT HOVENKAMP, ENTERPRISE AND AMERICAN LAW, 1836-1937, at 331-48 (1991) (discussing cartel of retail druggists that used RPM to limit price cutting).
} (dealer cartel). 
above marginal cost to particular customers. The amount of power is not substantial, however, and sufficient market power to have antitrust consequences cannot be inferred from the existence of price discrimination alone.

While price discrimination is often unrelated to market monopoly, it may result from bilateral monopoly. For example, a firm about to enter the fast food industry as a supplier can profit by sharing risk, and self-employed franchisees may have stronger incentives to do well than widely scattered employees would. If the firm built its own restaurants it would expect to earn from them in proportion to their relative success, and franchising is an attractive alternative to the extent that it replicates this opportunity while permitting franchisee to share the risk as well as part of the reward. For its part, the nascent franchisee receives a method of doing business, a recognized name and product, and the promise of high returns proportional to its level of success. So it willingly puts up its share of the capital (the franchisee fee), opens an outlet, and pays either a recurring fee proportional to sales or an overcharge on various tied consumable products used in the franchised business, or some combination. Ex ante, the franchisee knows that its payments are proportional to sales and one certainly cannot say that the prospect of high sales and accompanying high franchise fee is a deterrent. Once entered, these arrangements are profitable and also durable, even in competitive markets, because the value of a successful franchise is high and extraction is too costly in relation to the available alternatives. For example, a high volume McDonald's franchise is highly profitable and desirable to its owner, notwithstanding that it is also highly profitable to the franchisor and at little more expense than it incurs with the less successful franchisee.

In sum, the phenomenon that makes price discrimination possible in such cases is not monopoly, but rather the fact that assets are specialized and that transferring to attractive alternative arrangements is not costless. Down the road a highly successful franchisee may become resentful that its franchisor is earning high returns on this particular franchisee's business with no greater effort than it puts into the business of less successful franchisees. But that outcome is a feature of joint risk taking. In any event, resentment in this case is odd because the prospect that a particular franchisee would become highly successful would have acted ex ante as an inducement rather than a deterrent to entry.

The case of price discrimination in aftermarket products is similar. Many price discrimination ties involve arrangements in which the seller charges a below-market price $^{35}$ for a tying product, but overcharges on a tied product whose use varies with the intensity of use of the tying product. A printer plus a subsequent stream of replaceable ink cartridges is one example.

The aftermarket price discrimination tie is simply a conditional sale that may lead to a bilateral monopoly, depending on what is specified in advance. Going in, if the underlying market is competitive a customer may be able to choose between a more expensive printer with less costly cartridges, or vice versa. In Kodak the Supreme Court was aware of this and made something of the fact that Kodak may have changed its

\footnotetext{
${ }^{35}$ See Hovenkamp \& Hovenkamp, Tying Arrangements, supra note
} 
policy late in the copy machine's lifecycle. As a result customers may have gotten a different and less attractive bilateral monopoly deal than the one they had bargained for at the beginning. But that change in policy is not an antitrust problem, although it may involve contract law or tortious misrepresentation.

Already in the 1950s, Chicago school writing on variable-proportion ties saw them as price discrimination devices, ${ }^{36}$ and the case law had seen them as such far earlier. $^{37}$ This Chicago school story was not about transaction costs, however, but rather about the profitable ways in which a monopolist might extract its overcharge. The TCE story is, if anything even more benign because it starts out with a seller who is not necessarily a monopolist at all. As a result, the welfare gains from the output increases that attend price discrimination still apply and competition in the underlying market offers even further protection for consumers. For example, the Chicken Delight franchise tying arrangement, which the Ninth Circuit condemned, involved a nondominant franchisor who required franchisees to purchase various food items and cooking supplies from itself. ${ }^{38}$ The franchise fee was zero and the franchisor obtained its return entirely from the supplies. ${ }^{39}$ The tie very likely produced an increased number of franchises, increased product sales, and increased welfare by both general welfare and consumer welfare measures. But if for some reason it did not, customers could always go across the street to Kentucky Fried Chicken or McDonald's. In sum, TCE has extended the Chicago School analysis to the ubiquitous situations in which price discrimination ties are imposed by nonmonopolists.

Price discrimination ties, even by a monopolist, are rarely candidates for condemnation on that ground because in the great majority of cases they improve consumer as well as general welfare. In general, such ties involve second-degree price discrimination, which is typically more benign than third-degree price discrimination.

In a third-degree price discrimination scheme a seller is able to identify ex ante customers who exhibit differential willingness to pay for some good and charge them different prices. For example, a seller might charge commercial users of its stereo

${ }^{36}$ Bowman, supra note

${ }^{37}$ See Heaton-Peninsular Button-Fastener Co. v. Eureka Specialty Co., 77 F. 288 (6th Cir. 1896) ("These machines have been placed in the hands of shoe dealers . . . at the actual cost of the machines to the makers, they expecting a profit on their monopoly alone from the sale of fasteners or staples to those having the machine.").

${ }^{38}$ Siegel v. Chicken Delight, Inc., 448 F.2d 43 (9th Cir. 1971).

${ }^{39}$ See id. at 46-47:

Over its eighteen years existence, Chicken Delight has licensed several hundred franchisees to operate home delivery and pick-up food stores. It charged its franchisees no franchise fees or royalties. Instead, in exchange for the license granting the franchisees the right to assume its identity and adopt its business methods and to prepare and market certain food products under its trade-mark, Chicken Delight required its franchisees to purchase a specified number of cookers and fryers and to purchase certain packaging supplies and mixes exclusively from Chicken Delight. The prices fixed for these purchases were higher than, and included a percentage markup which exceeded that of, comparable products sold by competing suppliers. 
equipment $\$ 100$ and residential users $\$ 60 .{ }^{40}$ This type of discrimination creates a discontinuity in marginal valuation that transfers some sales from high-value to lowvalue customers. Consumer welfare can be reduced even if output remains constant. In this illustration, for example, a commercial user who valued the stereo at $\$ 90$ would be denied the sale. Rather, that unit would be sold to someone for $\$ 60$ even though she valued it at far less than $\$ 90$. As a result economists have known for nearly a century that third-degree price discrimination reduces welfare unless it results in an output increase.

By contrast, in the typical variable proportion tying case the seller reduces the price of the tying good and increases the price of the tied good; however, the latter price is the same for all. For example, a manufacturer might cut the price of its printer from the stand-alone amount of $\$ 400$ and instead charge $\$ 200$, but it would raise the price of tied cartridges from $\$ 25$ to $\$ 40$. In that case the seller would earn more from buyers who used the printer more intensely, because they consume more ink cartridges. The distortions come from the reduced price for the printer, which favors consumers and brings more of them into the market, but also from the increased price of the cartridge, which raises per use variable costs. ${ }^{41}$ Significantly, however, the higher cartridge price is the same for everyone. Such ties can benefit consumers in a wider variety of circumstances, even in the rare case where output falls as a result of the tie. ${ }^{42}$ Further, such arrangements are common even in competitive markets. In that case when consumers find them unfavorable they can always substitute away.

This analysis also suggests that vertical restraints that segregate buyers can be more harmful price discrimination devices than ties are. While variable proportion ties represent instances of second-degree price discrimination, segregation restraints discriminate in the third degree. For example, the manufacturer who uses vertically imposed customer restrictions to segregate customers by class, or the patentee who uses field-of-use restrictions for the same end, is engaged in third degree price discrimination. ${ }^{43}$ Welfare harm is more likely, although even here it should not be presumed.

TCE has also informed our understanding of exclusionary practices by dominant firms. One example is the well-known debate between Areeda and Turner against Oliver Williamson over the proper test for predatory pricing. Williamson believed that the Areeda-Turner predatory pricing test was too lenient and did not adequately address

${ }^{40}$ E.g., Gen. Talking Pictures Corp. v. W. Elec. Co., 304 U.S. 175 (1938) (field of use restriction distinguishing commercial and residential users); ProCD, Inc. v. Zeidenberg, 86 F.3d 1447 (7th Cir. 1996) (software licensing agreement distinguishing commercial and noncommercial users). See Christina Bohannan, IP Misuse as Foreclosure, 96 Iowa L. Rev. __ (2010).

${ }^{41}$ E.g., Xerox Corp. v. Media Sciences, Inc., 660 F.Supp.2d 535, 539 (S.D.N.Y. 2009) (noting that virtually all printer manufacturers tie by selling the printer at a price of cost or less, and place the overcharge in the expendable cartridges).

${ }^{42}$ Hovenkamp \& Hovenkamp, Tying, supra note .

${ }^{43}$ E.g., Gen. Talking Pictures Corp., 304 U.S. 175. See 8 PhilliP E. ArEeda \& HERBERT HOVENKAMP, ANTITRUST LAW IITI 1616e, 1647c5, 1641c (3d ed. 2010). 
the threats imposed by longer run strategic behavior. ${ }^{44}$ Another area in which TCE has reinvigorated the analysis of exclusionary practices is raising rivals' costs (RRC), which begins with the premise that many exclusionary practices are more easily rationalized as devices for increasing rivals' costs than as mechanisms for excluding them. In general, the RRC literature has attempted to restore a meaningful conception of anticompetitive exclusion without a return to the more severe apprehensions of the structuralist school, which tended to view rivals and smaller firms as anesthetized patients rather than as vigorous competitors who could respond in kind. ${ }^{45}$ Some Chicago school writers have been very critical. ${ }^{46}$ Resources are in fact quite mobile, but transaction costs and the other attendant costs of resource movement must be taken into account as well.

"Exclusionary" distribution agreements can present analogous problems in transaction cost analysis. For example, interbrand free riding can be a particular problem for manufacturers dealing through multibrand retailers. ${ }^{47}$ Ordinarily a manufacturer engaged in self-distribution would not have an incentive to retail the products of rivals in addition to its own. Exclusivity arrangements imposed on dealers can make the manufacturer/dealer relationship behave more like a single firm would behave. Nevertheless, in a few cases exclusive dealing and foreclosing ties can also impair competition. ${ }^{48}$ Other things equal, a dealer and its customers are best off when supply markets are competitive, and unreasonably exclusionary arrangements can prevent such competition from developing.

TCE has served to limit antitrust analysis from the structuralist expansionism of the 1970s and earlier, but also as a corrective for those inclined to see the movement of resources as essentially costless. Both are extremes that antitrust policy should avoid.

${ }^{44}$ See Phillip E. Areeda \& Donald F. Turner, Predatory Pricing and Related Practices Under Section 2 of the Sherman Act, 88 HARV. L. REV. 697, 698 (1975); Williamson's principal response, Oliver E. Williamson, Predatory Pricing: A Strategic and Welfare Analysis, 87 YALE L.J. 284 (1977); and the reply, Phillip E. Areeda \& Donald F. Turner, Williamson on Predatory Pricing, 87 YALE L.J. 1337 (1977). The debate and the current position of Antitrust Law are developed in 3A AREEDA \& HOVENKAMP, supra note 38, গTI 729, 736 at 106-121, 135-156.

${ }^{45}$ See, e.g., Thomas G. Krattenmaker \& Steven C. Salop, Anticompetitive Exclusion: Raising Rivals' Costs to Achieve Power over Price, 96 YALE L.J. 209 (1986); Steven C. Salop \& David T. Scheffman, Raising Rivals' Costs, 73 AM. ECON. REV. 267 (1983).

${ }^{46}$ See, e.g., RICHARD A. POSNER, ANTITRUST LAW 196 (2d ed. 2001) (describing RRC as "not a happy formula"). One prominent Chicago school economist sees much more promise in the theory of RRC, but also difficulties in administration. See Dennis W. Carlton, The Relevance for Antitrust Policy of Theoretical and Empirical Advances in Industrial Organization, 12 GEO. MASON L. REV. 47, 50-54 (2003). On the Chicago school and RRC, see Herbert Hovenkamp, Exclusion and the Sherman Act, 72 U. CHI. L. REV. 147, 159-60 (2005).

${ }^{47}$ See, e.g., 11 HERBERT HOVENKAMP, ANTITRUST LAW II 1812 (3d ed. 2011).

${ }^{48}$ See, e.g., 9 id. IIII 1704, 1709 (foreclosure). 